\title{
SPECIES COMPOSITION AND SOIL CHARACTERISTICS BETWEEN GRAZING FORAGE SYSTEMS AND CUT AND REMOVED FORAGE SYSTEMS IN WALAWE REGION
}

\author{
S.H. Muditha Manjula \& Thakshala Seresinghe \\ Department of Animal Science, Faculty of Agriculture, \\ University of Ruhuna
}

Botanical composition and soil parameters of grazing and cut and removed forage systems in five villages (Barawakumbuka, Manadala, Nonagama, Bolana, Ambalantotoa) Walawe region were studied to observe the impact of different management systems on the productivity of plant and soil sharacteristics. Herbage and soil samples were collected randomly using a quadrate $\left(50 * 50 \mathrm{~cm}^{2}\right)$ from five grazing and five cut and removed sites. Samples ( 3 replicates) were collected three times from each locations during the following periods. Herbage from grazing lands consisted $85 \%$ grasses and $15 \%$ other species. Prostrate grass species such as Eleusine indica and Chrysopgon aciculatus, were dominant and improved groundcover. Moisture (20.04\%) retention in the grazed soil was significantly increased due to the improvement of ground cover with increasing the potential for soil conservation. Herbage collected from cut and removed sites consisted $70 \%$ grasses and $30 \%$ other specics.

Dominant plants were tufted spccies such as Pennisetum polystachyon, Grewia corpinifolia and Leucaena leucocepha. Moisturc (6.13\%) retention in these sites was significantly lower as compared with grazed sites.

Soil collected from grazing sites had higher $\mathrm{pH}(7.88)$ as compared to the cut and removed sites (6.13). This may be due to recycling of nutrients via dung and urine. Threading by animals, which may cause a packing of the soil particles and loss of the large pores in the soil mass increased the bulk density $\left(1.34 \mathrm{~g} / \mathrm{cm}^{3}\right)$ of the grazing sites as compared with the soil of cut and removed sites $\left(1.16 \mathrm{~g} / \mathrm{cm}^{3}\right)$. This would have been reduced the porosity of the soil in grazing sites $(24.96 \%)$ as compared to the soil in cut and removed sitcs (46.86\%).Although the bulk density of the grazing soils was negatively affected by threading, ground cover, moisture retention and spatial redistribution of mineral nutrients are influenced by grazing management as compared with cut and removed systems. Therefore, it can be suggested that grazing management is more suitable for low input output subsistence farming systems in the Walawe region.

Proceedings of the Eighth Annual Forestry and Environment Symposium 2002 of the Department of Forestry and Environmental Science, University of Sri Jayewardenepura, Sri Lanka 